\title{
Czytanie pamięci - doświadczenie - emocje. Narracje literackie dla młodego czytelnika - teoria i praktyka odbioru (Rutka Joanny Fabickiej)
}

\author{
Reading memory - experience - emotions. Literary \\ narratives for children and young adults - theory \\ and practice of reception (Rutka by Joanna Fabicka)
}

\author{
Dorota Michułka \\ Uniwersytet Wrocławski \\ Łukasz Gregorowicz \\ Szkoła Podstawowa nr 108, Wroctaw
}

\begin{abstract}
The article is based on empirical research related to reading, experience and emotions, conducted in primary schools for several years. The story of Joanna Fabicka Rutka (2016) has become the exemplification for the mentioned empirical research. A polysensory, but also poetic in the illustration of the world, fairytale literary narrative about the destruction and the recovery of a lost childhood, kept in the poetics of magical realism. The book deals with the topics of dialogue between genders, friendship, the power of imagination, memory, understanding, naming and tame emotions, loneliness and fear of death. The book also shows the problem of settling with a difficult past (here: war trauma), the responsibility of adults and growing up to dreams. Visualization of the effects and affect of narrative fragments and metaphorisation of images reinforced by real experience, as noted in the story, may affect the reader's emotional involvement and influence the construction of new meanings and meanings of the work, which all translates into support of understanding, shaping the imagination and ethical formulation of reflection on the world.
\end{abstract}

Key words: cognitive reading; emphatic reading; immersive reading; visual narration; multisensory narration; identification with protagonist; figures of memory; post-memory

Streszczenie: Artykuł opiera się na badaniach empirycznych związanych z czytaniem, doświadczeniem i emocjami, prowadzonych w szkołach podstawowych od kilku lat. Egzemplifikacją dla badań empirycznych stała się, w tym przypadku, polisensoryczna, ale i poetycka ze względu na obrazowanie świata - baśniowa narracja literacka o zagładzie, o odzyskiwaniu straconego dzieciństwa, utrzymana w poetyce realizmu magicznego opowieść Joanny Fabickiej Rutka (2016). Książka porusza tematy dialogu pokoleń, przyjaźni, siły wyobraźni, pamięci, rozumienia, nazwania i oswojenia emocji, samotności i lęku przed śmiercią, a także ukazuje problem rozliczenia z trudną przeszłością (tu: wojenną traumą), odpowiedzialności dorosłych oraz dorastania do marzeń. Wizualizacja efektów i afektów fragmentów narracji oraz metaforyzacja obrazów wzmacnianych doświadczeniem rzeczywistym - jak zauważono - może wpływać na emocjonalne zaangażowanie czytelnika oraz 
wywierać wpływ na konstruowanie przez niego nowych znaczeń i sensów utworu, co przekłada się w tym przypadku na wspomaganie rozumienia, kształtowanie wyobraźni i formułowanie etycznej refleksji nad światem.

Słowa kluczowe: czytanie kognitywne; czytanie empatyczne; czytanie imerysje; narracja wizualna; narracja polisensorczna; identyfikacja z bohaterem; figury pamięci; post-pamięć

\section{Kognitywizm - czytelnictwo - projektowanie sytuacji dydaktycznych - założenia metodologiczne}

„Wśród uzasadnień dla empirycznych badań literatury obserwujemy jedną istotną część wspólną - chęć przeniesienia punktu ciężkości w literaturoznawstwie z wiedzy czysto akademickiej na grunt pragmatyczny, tj. oddziaływania literatury na jednostkę" (Maryl 2013; Rembowska-Płuciennik 2009) w tym także młodego odbiorcę, np. ucznia w wieku szkolnym. W wielu pracach poświęconych "szkolnej lekturze” (Janus-Sitarz 2009, 2016) dostrzeżono także kwestie „emocji literackich” (Papuzińska 1995; Zasacka 2014; Małecki, 2016) i „emocjonalnej percepcji”. Zofia Budrewicz pisze: „Sytuację odbioru dzieła artystycznego wyprowadza [się już] z antropologii literatury i kulturowej teorii liteatury (...). Autorzy wielu prac [zmierzając w stronę poznawania przez doświadczenie] wiążą operacyjną przydatność figury podmiotowego doświadczenia sensualno-mentalnego z możliwościami „wglądu“ w nie odbiorcy - ucznia“ (Budrewicz 2012, 6), emocjonalnego zaangażowania realnego czytelnika, czytania empatycznego i afektów (Koziołek 2016; Miall 2006; Opdahl 2002; Paivio 2007; Galda 2002). W wielu przypadkach punktem wyjścia staje się ujęcie kognitywistyczne podejmujące „uwarunkowania ludzkiej percepcji, pamięci i zawsze noszące ślad procedur znaczeniotwórczych"1.

Jak zauważają Miall i Kuiken, „zasadniczą funkcją czytania literatury jest wyposażenie nas w narzędzia do lepszego rozumienia i reagowania na nasze otoczenie" (Miall i Kuiken 1998, 340) 2

W niniejszym artykule, który powstał w wyniku kilkuletnich badań, jakie prowadzimy z uczniami w szkole podstawowej, interesuje nas wypracowanie nowej formuły analizy i języka dydaktyki szkolnej w zakresie literatury - tu głównie języka zaangażowania w czytanie sfunkcjonalizowane wobec potrzeb emocjonalnych, społecznych i kulturowych (Rajtar, Straczuk 2012), które literatura zaspokaja. Także u młodych czytelników. Punktem wyjścia stanie się specyfika emocjonalno-sensualnego odbioru narracji literackiej - np. żywe obrazowanie mentalne absorbujące wielu czytelników

1 Definicję kognicji przyjmujemy za The Oxford Companion to the Mind, 1987, Gregory L.R. (red.), Oxford University Press, i zakładamy, że jest to: „złożona wielość ludzkich procesów poznawczych, sposoby używania i kumulowania wiedzy, także uwarunkowanie ludzkiej percepcji, pamięci, zawsze noszących ślad procedur znaczeniotwórczych"; cyt. za: Rembowska-Płuciennik 2009.

2 Zob. także Maryl M., Interpretator czy czytelnik? Projekt badań empirycznych nad stylami odbioru, http://www.academia.edu/5544682/Interpretator_czy_czytelnik_Projekt_bada\%C5\%84. empirycznych nad_stylami_odbioru; Markowski 2000. 
(także na zasadzie intersubiektywnej kooperacji) oraz cztery teoretyczne zagadnienia:

- transactional theory of reading response (strategie „life-to-text” i,,text-to-life” ) a więc tekst, czytelnik rzeczywisty i jego świat;

- czytanie estetyczne i eferentne (zakładające wyjście poza tekst - Rosenblatt 1995);

- jednostkowość, indywidualność i prywatność odczytań (Rosenblatt 1995; Galda 2013);

- $\quad$ trzy aspekty badań afektów: 1. Self- reference („ja i mój świat“); 2. Domain-crossing (krzyżowanie różnych perspektyw oglądu tekstu); 3. Anticipation (przewidywanie, antycypowanie rezultatów, ewokowanie skojarzeń, badanie horyzontu czytelniczych oczekiwań) (Miall 1989).

Praca z tekstem w szkole w trakcie naszych badań opiera się na czterech założeniach:

- $\quad$ po pierwsze - tekst jest kategorią multimodalną i wielozmysłową (a nie tylko językową);

- $\quad$ po drugie - zakładamy multisekwencyjność procesu czytania (a nie czytanie gotowego tekstu);

- po trzecie - proces czytania „to nie tylko interaktywność medialna, ale także interaktywność samego procesu percepcji. Tekst jest nie tyle obiektem, lecz projekcją wewnętrznego umysłu czytającego. I wykorzystuje zakorzenione w percepcyjnych doświadczeniach cielesnych, codziennych kontaktach ze światem zewnętrznym - konceptualne (abstrakcyjne reprezentacje pojęciowe) - schematy wyobrażeniowe” (Płuciennik 2014, 2). Obrazy mentalne przyjmują tu funkcję metafor pojęciowych, gestaltu doświadczeniowego. Gestalt doświadczeniowy rozumiemy jako odwoływanie się do codziennych doświadczeń i tworzenie ramy konceptualnej, która wpływa na nasz sposób myślenia o określonym zjawisku. Gestalt doświadczeniowy to jak ludowa mądrość - „wielowymiarowa całość o określonej strukturze” - twierdzą George Lakoff i Mark Johnson - pewien złożony obraz, który pojawia się w zetknięciu z określoną sytuacją; metafora-mem, która dociera do naszego umysłu, nie jako zbiór pojedynczych obserwacji, które dopiero w procesie „rozumienia”, „rozumowania” lub „myślenia” łączymy w całość, ale „obraz”, który już na etapie postrzegania otaczającego nas świata łączy nasze doznania w spójne całości (Stockwell 2006; Lakoff i Johnson 2010, 29-35; Płuciennik 2002, Maryl 2005, 2016).

- po czwarte - „skupienie na narracjach literackich [dla dzieci, D.M.] wiąże się z (...) przekonaniem o tym, że lektura narracji fikcjonalnych zaspokaja wyjątkowe potrzeby emocjonalno-poznawcze człowieka Doświadczeniowy charakter odbioru literackiego, 
osiągamy przez „wniknięcie w fikcję”, co [może] stanowić dla wielu [młodych] czytelników niepowtarzalne i intensywne doznanie porównywalne $\mathrm{z}$ doświadczeniem wirtualnej rzeczywistości czy poruszaniem się w interaktywnym środowisku interfejsu" (Rembowska-Płuciennik 2015, 14). Podobnie rzecz ujmują także inni badacze narracji literackich i poetyki odbioru: Ryan (2003), Nikolajeva (2014), Hunt (1985).

Egzemplifikacją dla prowadzonych przez nas badań empirycznych stała się polisensoryczna, ale i poetycka ze względu na obrazowanie świata - baśniowa narracja literacka o zagładzie, o odzyskiwaniu straconego dzieciństwa, utrzymana w poetyce realizmu magicznego, oniryzmu w stylu Brunona Schulza, częściowo także groteski - Rutka (2016) Joanny Fabickiej. Opowieść porusza tematy dialogu pokoleń, przyjaźni, siły wyobraźni, pamięci, rozumienia, nazwania i oswojenia emocji, samotności i lęku przed śmiercią, a także problem rozliczenia z trudną przeszłością (tu: wojenną traumą), odpowiedzialności dorosłych oraz dorastania do marzeń. Jest to także opowieść o wojnie ukazana za pomocą osieroconych przedmiotów np. walizek i kufrów, talerzy, sztućców, solniczek. Dziesięcioletnią Zosią, której mama jest ciągle zajęta, opiekuje się ekscentryczna ciotka Róża, która porusza się na wózku. Staruszka niekonwencjonalnie się ubiera, jest tajemnicza i pilnie skrywa w kufrze trudną przeszłość swojego życia. Ciotka ma jednak poczucie humoru i rozumie samotność dziewczynki. Zosia mieszka w starej kamienicy mieszczącej się przy zniszczonym, ponurym podwórku, w sąsiedztwie odrapanych, opuszczonych domów. Pewnego dnia spotyka na swej drodze rówieśnicę z rudym warkoczykiem, i... przenosi się wraz z nią w wojenną przeszłość. Rutka - dziewczynka z przeszłości - jest żydowskim dzieckiem, które straciło rodziców. Bohaterka - sama, zawsze głodna - w opuszczonym mieszkaniu potrafi „bawić się w rodzinę”. Rysując na ścianach i podłodze wyobrażonych rodziców i brata, wciela się w ich role, inicjuje rodzinne dialogi z przeszłości. Dziewczynki stają się sobie wyjątkowo bliskie i „wymieniają” się światami. Rutka „wciąga” Zosię do „swej” przeszłości i jak prawdziwy przewodnik pokazuje jej wojenną rzeczywistość - ucząc, jak przetrwać trudne chwile. Dziewczynki wędrują przez smutne i szare ulice Łodzi, rybny bazar, doświadczają podróży zatłoczonym tramwajem, poznają dworzec, na który wjeżdżają zaryglowane wagony z ludźmi. Przełamując lęk i strach, Rutka „zaprasza” Zosię do niekończącej się „zabawy w chowanego” (czyli notorycznego ukrywania się przed wrogiem). Zosia - tak jak Rutka - wypracowuje z czasem własną - wewnętrzną - wyobrażoną przestrzeń istnienia. Wydaje się, że wzmocniona imaginacją i etycznie nacechowana, „inna” przestrzeń bohaterki/„inne” przestrzenie bohaterek - jak heterotopia 
(Foucault 2005) ${ }^{3}$ - znajdują się gdzieś „pomiędzy” dwoma światami: rzeczywistym - współczesnym i wyobrażonym - światem z przeszłości. Prowokacja czytelnika osadza się w opowieści Fabickiej na konfrontacji rzeczywistości współczesnej ze światem z przeszłości, co determinuje dynamiczny charakter działań bohaterek i kreuje wypowiedzi o charakterze emocjonalnym (np. smutku, żalu, przygnębienia i współczucia, ale także zdziwienia, podziwu i niezgody). Narracja czasu nakłada się w powieści Fabickiej na narrację miejsca i przyjmuje kształt Bachtinowskiej czasoprzestrzeni (kulturowego chronotopu), łącząc wcielenia melancholii z topografią straty (Wójcik-Dudek 2016).

Rutka wpisuje się wyraźnie w niemały już dzisiaj w Polsce krąg utworów literackich dla dzieci, których tematem jest Holokaust i zjawisko „post-pamięci” (Hirsch 1997; Assmann 2009; Tych 2009, 41-55; Szuchta 2008; Ulanowicz 2013) - realizowane w opowieściach utrzymanych w stylistyce poetyckich baśni, osadzonych w światach odrealnionych, np. Joanny Rudniańskiej XY (2012) oraz Kotka Brygidy (2007) czy Marcina Szczygielskiego Arka Czasu (2013). Są to powieści o charakterze fantastycznym, z wyraźnym moralnym i egzystencjalnym przesłaniem, odwołują się także do poetyki realizmu magicznego, stylistyki baśni postmodernistycznych, baśni-paraboli, często przywołują prawdziwe zdarzenia i rzeczywiste losy ludzi żyjących w czasach wojny (Kokkola 2003; Vice 1997, 201; Kertzer 2002; Etkind 2013).

Pamięć drugiego pokolenia jest formą pamięci zbiorowej, która w opowieści o Rutce krzyżuje się z pamięcią indywidualnej świadomości - ma charakter palimpsestowy, selektywny, szkicowo-fragmentaryczny, łączy pamięć świadków bezpośrednich i „spóźnionych”, działa na wyobraźnię czytelnika przez gesty, przedmioty, oderwane sceny, obrazy symboliczne oraz mentalne i - w przypadku dziecięcego odbiorcy - odnosi się do pojęcia pokolenia. Powieść Fabickiej pozwala na eksplorowanie fenomenu pamięci z perspektywy współczesnej, na uwzględnienie zmiennego oraz dynamicznego charakteru pamięci oraz na subiektywizm opisu, który inspiruje, ożywia i aktywizuje ją ${ }^{4}$.

\footnotetext{
${ }^{3}$ „Nie żyjemy w przestrzeni homogenicznej pustej, ale wręcz przeciwnie - w przestrzeni nasyconej jakościowo i zapewne także nawiedzanej przez fantazmaty. Przestrzeń naszej pierwotnej percepcji, przestrzeń naszych snów i naszej namiętności posiada jakości niejako wewnętrzne, to przestrzeń lekka, eteryczna, przezroczysta lub ciemna, nierówna, zatłoczona; przestrzeń z góry, przestrzeń szczytów, lub przestrzeń z dołu, przestrzeń błota, przestrzeń, w które może płynąć woda, przestrzeń zatrzymana, zakrzepła, jak kamień lub kryształ", Foucault M., 1984, Of Other Spaces: Utopias and Heterotopias w: Architecture /Mouvement/ Continuité, October, ("Des Espace Autres," March 1967, tłum. z j. franc. Jay Miskowiec), s. 2-3, (tłumaczenie na j. polski- D.M.).

4 „Second- generation memory is a form of collective memory that involves an individual's conscious incorporation of her elder's memories of a traumatic past within her own mnemonic repertoire. (...) [it] involves an individuals internalization and subsequent narrative reinterpretation of her elder's remembered past (...) as a "memory of the family" (...) it is produced (...) not by "personal feelings but by rules and customs" that is traditionally characterize pre- existing kinship relations (...) It is characterized by a profound self - awareness (...) in a sense of participation in, a given demographic's shared narrative of its past (...) and with recognition of the ways in which her present circumstances have been mediated and shaped by past events that she herself did not directly experienced" (Ulanowicz 2013,4).
} 
Teksty literackie poruszające zagadnienie pamięci mogą zatem prowokować do badań o charakterze kognitywistycznym.

\section{Metafora i doświadczenie w funkcji afektywnej - przestrzeń i czas - podwórko, przeniesienie do innego świata}

W Poetyce kognitywnej (Stockwell 2006) pojawiają się określenia: uczuciowy aspekt literatury oraz „doznawanie i pojmowanie literatury”. Doznawanie literatury jest interpretowane jako „racjonalne dokonywanie wyborów i twórcze konstruowanie znaczenia”. „Pojmowanie” wiąże Stockwell natomiast z istotnym aspektem literatury, która łączy projekcję poznawczą i uczuciową z wyobrażeniową ${ }^{5}$.

Przypominamy w tym miejscu istotną dla niniejszych rozważań teorię czytania estetycznego i eferentnego oraz „interactional reading” Loise Rosenblatt (Literature and exploration, 1995). W szkolnym procesie odbioru literatury „interactional reading” zakłada kontekst rzeczywistości pozaliterackiej oraz prywatną, także egzystencjalną potrzebę lektury:

skupienie czytelnika na tekście (jako zdarzeniu) uaktywnia w jego dotychczasowych doświadczeniach wybrane elementy - zewnętrzne odwołania i wewnętrzne reakcje, które zostały zespolone z symbolicznymi znaczeniami słów. Znaczenie wyrasta z sieci relacji pomiędzy symbolicznymi elementami według intuicji czytelnika. Symbole prowadzą do obrazów, obiektów, idei, związków poprzez konkretne skojarzenia lub odczucia - utworzone poprzez związane z nimi dotychczasowe doświadczenia w „prawdziwym życiu” lub też w literaturze (Rosenblatt 1994, 11).

Z powyższą tezą koresponduje wyraźnie wykorzystanie $\mathrm{w}$ badaniach empirycznych narratologii kognitywistycznej i strategii intersubiektywności. Stanowi ona - zgodnie z ustaleniami Rembowskiej-Płuciennik -

szereg strategii poznawczych i zdolności, umożliwiających nam wieloperspektywiczny ogląd świata, sytuacji własnej oraz postrzeganego innego człowieka (...). Umiemy myśleć o swoim i cudzym myśleniu (reprezentować mentalnie wiedzę), umiemy rozpoznawać i odczuwać cudze emocje i nastawienia, umiemy wyobrażać sobie nie tylko przestrzeń z innego punktu obserwacyjnego, ale i stan wewnętrzny nieistniejącego realnie człowieka... (Rembowska-Płuciennik 2015, 11-12).

Wydaje się, że dziecięcy odbiór lektury może być „wzmocniony” bogatym światem wyobraźni dziecka, jego ciekawością poznawania świata, świeżością spojrzenia, spontanicznością, naturalnością w wyrażaniu reakcji na utwór, a przede wszystkim - związany z procesem rozwoju psychicznego - nieograniczonym/nieobjętym normami społeczno-kulturowymi - wyrażaniem uczuć i emocji (przytaczam tu dla przykładu kilka wypowiedzi dzieci

\footnotetext{
${ }^{5}$ Kognitywistyczne badania nad odbiorem literatury (także „szkolnym czytaniem”) - jako subdyscyplina badań teoretycznoliterackich skupiają się nad: 1. rozumieniem narracji; 2. postaciami; 3. emocjonalnym oddźwiękiem czytelniczym; 4. zapamiętywaniem tekstu; 5 . wizualizowaniem jako stylem odbioru (Rembowska-Płuciennik 2008, Nikolajeva 2015). W opracowaniu niektórych części teoretycznych artykułu korzystałam z ustaleń kognitywisty Mateusza Mareckiego, któremu bardzo dziękuję za wnikliwą lekturę tekstu i owocne konsultacje.
} 
z publikacji Lee Galdy - „this book inhale me!”, „hurt me!“, „make me laugh“, „I was crying“ (Galda 2013).

Powyższe tezy potwierdzają także rezultaty badań polskich dydaktyków literatury, np. Jana Polakowskiego, Tadeusza Patrzałka. Ich badania odwoływały się do naturalnego odbioru czytelniczego dzieci w młodszym wieku szkolnym i prowadziły do wniosku, że dziecko czyta utwór literacki dla zaspokojenia potrzeb ludycznych i kompensacyjnych (Polakowski 1980; Patrzałek 1980, 1982). Ponadto - „lubi rozpoznawać rzeczy dobrze znane i dobrze się czuje wśród spraw swojskich. Zauważa konkrety - zdarzenia, szczegóły, postacie, nie ogarnia całości. Czyta z właściwym jego rozwojowi myśleniem subiektywnym, synkretycznym i fragmentarycznym - spostrzega i zapamiętuje to, co chce, co je zainteresowało poprzez relacje do osobistych doświadczeń lub dowolnych skojarzeń” (Żuchowska 1992) ${ }^{6}$.

$\mathrm{Na}$ tym etapie rozważań wybieramy do analizy cztery fragmenty narracji Fabickiej - opis rzeczywistego miejsca - rodzinnego domu bohaterki, reprezentacje przestrzeni wyobrażonej w sytuacji pierwszego spotkania Zosi z Rutką oraz - po przeniesieniu bohaterki w czasie - fragment ukazujący Łódź czasów wojny (w tym ulice, bazar oraz łódzki dworzec).

Fragmenty przyjmują w opowieści funkcję swoistych obrazów mentalnych, charakteryzują się polisensorycznością narracji i odsyłają do świata emocji (ich doświadczania, nazywania i opisywania) (Rembowska-Płuciennik 2016; Paivio 1971, 1991, 2007). Obraz mentalny rozumiemy natomiast jako

specyficzny rodzaj mentalnej reprezentacji, wyróżniający się powiązaniem z systemem perceptualnym. (...) Największe znaczenie mają tu niewątpliwie obrazy wizualne, gdyż widzenie odgrywa główną rolę w procesach poznawczych oraz w bezpośredni sposób wiąże się z dostępem do przedmiotów zewnętrznych, manipulowaniem nimi oraz z orientacją w przestrzeni (Rembowska-Płuciennik 2009, 120-21).

\section{Fragment pierwszy - podwórko domu rodzinnego Zosi}

\section{Zosia mieszka przy ul. Rybnej 13 na Bałutach w Łodzi.}

Jakie skojarzenia budzi w tobie miejsce zamieszkania głównej bohaterki? Miejsce - przestrzeń jako fragment rzeczywistej mapy miasta „osadza“ bohaterkę w konkretnej scenerii, a dzięki poetycko-wizualnej narracji wprowadza czytelnika w tajemniczą, mroczną, ponurą, upiorną (jak piszą uczniowie) atmosferę opowieści. Fragment budzi w uczniach niepokój i grozę:

${ }^{6} \mathrm{~W}$ rozważaniach na temat poetyki odbioru warto zwrócić uwagę jeszcze na głos Bożeny Chrząstowskiej, która na podstawie rysunków dziecięcych wyróżniła odbiór faktyczny, refleksyjny, symboliczny. Zilustrowała je, analizując m.in. rysunkowe konkretyzacje wiersza T. Różewicza Bursztynowy ptaszek. Zob. Chrząstowska B., 1987, 129-140. Martin Lindauer natomiast podkreśla, że „proces lektury jest jednak procesem psychologicznym [a] <<literatura posiada odniesienie kognitywne [cognitive referent], jako że jej zawartość i struktura wywołują w czytelniku marzenia, poglądy na znaczenie i wyczucie stylu >>". Żeby bardziej uporządkować kwestię procesów psychologicznych w trakcie lektury, sięgnijmy także po definicję interpretacji Jerry’ego Hobbsa, badacza dyskursu, który pojmuje ją jako „funkcję dwóch argumentów: tekstu i zbioru przekonań“ [czytelnika - M.M.] (Lindauer 1974, 139). 
Blade światło wylewa z mroku fragment tak dobrze znanego Zosi podwórka. Z czterech stron otaczają je niewysokie domy, z których trzy są zamieszkałe, a czwarty - najniższy i najbardziej zniszczony - od wielu lat stoi pusty. Wybite szyby i spróchniałe belki stropu odstraszają nawet najodważniejszych (...). Wszystkie cztery budynki tworzą wokół podwórza coś na kształt betonowej studni, do której od ulicy prowadzi obdrapana brama z zepsutym domofonem. Wewnątrz nie ma jednak wody, tylko szary, duszny pył - wypalony teraz przez słońce, wchodzący w oczy i uszy, zatykający nos. Jedynym zielonym punktem, w tym jakby ulepionym z popiołu świecie, jest samotna wierzba, rosnąca w samym sercu podwórza. Jej rozłożyste korzenie tkwią zabetonowane głęboko pod ziemią i tam toczą swe tajemne, niewidzialne dla oczu życie. Zosia obserwowała, jak od lat próbują przebić ten beton i wydostać się na powierzchnię (...). Jednak ostatnio drzewo ma coraz mniej sił. Z każdym miesiącem, niczym staruszka, coraz bardziej chyli się ku ziemi, na jego pniu pojawiają się zgrubienia i narośle, a liście są mniejsze i już nie tak zielone jak dwaniej (Rutka, s. 10-11).

\section{Uczniowie piszą:}

A - „Podwórko, przy którym mieszkała Zosia, jest stare, zaniedbane i smutne; jakby czas się tam zatrzymał"; „Przypomina mi stare osiedla, z których wyprowadzili się/wyjechali wszyscy młodzi“.

B - „Opisana wierzba może symbolizować ludzkie życie, ponieważ wierzba rośnie tak jak człowiek. W pewnym momencie przestaje rosnąć jak człowiek. Wierzba w końcu usycha - co oznacza śmierć"; „wierzba może symbolizować to, żeby w końcu w siebie uwierzyć"; „Wierzba symbolizuje samotnośćc; „Symbolizuje człowieka, który próbuje spełnić swoje marzenia, (...) być może chce się wydostać z takiego środowiska, jakim jest to podwórko“.

W wypowiedziach dzieci występuje wyraźne nawiązanie do własnych lub wyobrażonych doświadczeń, a opis przestrzeni prowokuje skojarzenia związane z kontekstami społecznymi (puste zaniedbane miejsce to miejsce opuszczone przez ludzi). Wierzba, która „próbuje przetrwać na betonowym podwórku“, symbolizuje dla dzieci samotność ludzi i ludzkie życie. W wypowiedziach uczniowie podkreślają upływ czasu („zatrzymanie czasu“) oraz atmosferę przygnębienia, smutku, żalu, zagubienia i samotności.

\section{Fragment drugi - pierwsze spotkanie Zosi z Rutką}

Scena, w której Zosia próbuje dogonić Rutkę, biegnąc za miasto.

Pierwsze zetknięcie ze światem wyobrażonym jest w opowieści Fabickiej momentem wyraźnego „ożywienia” narracji i stanowi także swoisty czytelniczy bodziec o charakterze emocjonalnym.

Stylizowana na awangardową ilustracja ze względu na nagromadzenie geometrycznych kształtów i ostrych linii wzmacnia tu przekaz słowny - intensywność czerwieni to intensywność uczuć - wywołuje u dzieci skojarzenia z dynamiką, działaniem, energią, żywiołem, ale także pragnieniem zdobycia czegoś lub kogoś i symbolizuje wielką chęć realizacji marzeń. Obraz ma charakter symboliczny, tym bardziej że - jak dostrzegają 
uczniowie - daleko w przedzie na ilustracji widać zarys uciekającej postaci z powiewającym na wietrze rudym warkoczykiem. Dzięki tej scenie konfrontacja dwóch światów - rzeczywistego i fantastycznego/wyobrażonego - staje się nie tylko oświetleniem narracji słownej, ale również katalizatorem zdarzeń. Ponadto czytelniczą uwagę zatrzymuje także pojawiający się w tekście świat dorosłego - funkcje emotywne wizualnej narracji tego fragmentu wzmacnia bowiem jeszcze dziecięca wyobraźnia bohaterki skonfrontowana ze skostniałym i na wskroś realnym/rzeczywistym myśleniem dorosłych (Bachelard 1975).

\begin{abstract}
Przed nią rozciąga się wielkie, niekończące się pole... czerwonych traw! Czerwonych jak truskawki, pomidory, jak lakier, którym mama często maluje sobie paznokcie i którym Zosia pomalowała sobie kiedyś policzki, ale to nie był dobry pomysł. Świat wygląda zupełnie jak na rysunku narysowanym przez Zosię jeszcze w przedszkolu (pani wyjaśniła jej wtedy, że trawa jest zielona. Zielona i kropka. Upierała się tak długo, aż Zosia dla świętego spokoju wszystko przemalowała). Pośrodku zwariowanego, odrealnionego krajobrazu stoi dziewczynka z rudym warkoczykiem (...). Nagle czerwona łąka zamienia się w rwący potok i trzeba kombinować, jak się nie zmoczyć. (...) Ale ta rzeka też jest... czerwona - duka Zosia. - Rzeki są niebieskie... Skąd wiesz? - ruda dziewczynka przyglądała się jej z drwiącym uśmiechem. - Mówisz zupełnie tak samo jak dorośli: „Rzeka jest niebieska, trawa zielona, a deszcz mokry". Zapamiętaj sobie, że dorośli nie są zbyt rozgarnięci i dlatego widzą tylko niektóre rzeczy. Dla ich własnego bezpieczeństwa, rzecz jasna. - A co by się stało, gdyby widzieli czerwoną trawę? - Gdyby widzieli to wszystko, co widzą dzieci... - no? To co by się stało? - To proste: zwariowaliby. Ich wyobraźnia nie obejmuje takich skomplikowanych spraw (Rutka, s. 50-52, 54-55).
\end{abstract}

\title{
Fragment opisu Łodzi z czasów wojny
}

Momentem kulminacyjnym w narracji opowieści, a jednocześnie „prowokacją czytelnika”, jest osadzenie bohaterki ze współczesności w świecie przeszłości. Przeniesienie w czasie odsłania sytuację konfrontacji dwóch skrajnie różnych etycznie światów - natomiast „zanurzenie” narracji w obrazach zniszczonego wojną miasta oswaja wyraźnie przyjaźń dziewczynek, które wędrują po mieście, trzymając się za ręce.

Uczniowie dostrzegają, że obraz ulicy Rybnej jest smutny, przygnębiający i ponury, przywołuje atmosferę zagubienia i nerwowości. Zauważają, że Zosia rozpoznaje miejsca, lecz wyglądają one inaczej, bo czas zniekształca rzeczywistość i „odbija“ przestrzeń jak w starym lustrze:

Przed budynkiem po drugiej stronie kłębi się istny tłum. Zosia nigdy nie widziała tu tylu ludzi. Wszyscy mówią jednocześnie, próbując się wzajemnie przekrzyczeć. Wznoszą w górę jakieś pakunki, wymachują papierami, ktoś płacze, ktoś krzyczy. Po bruku toczy się załadowany po brzegi wóz zaprzężony w chudego konia. Wszystko wokół wygląda tak, jakby się właśnie przeprowadzali albo nagle postanowili wyjechać na wakacje. Jednak nie wiadomo czemu, nie ma tu radosnej atmosfery. Wyczuwa się zdenerwowanie i pośpiech. Jakaś kobieta klęczy nad rozbebeszoną walizką i mówi sama do siebie. Ze wszystkich stron dobiegają słowa, których 
nie sposób zrozumieć: niemieckie, francuskie, angielskie, czeskie. Skąd wziął się tu cały świat? (Rutka, s. 80).

Stoją tu te same domy, rosną podobne drzewa, tylko nie wiadomo czemu, wszystko wygląda jak z dawnych, czarno białych kronik filmowych albo starych gazet, (...) wszyscy ubrani są dziwacznie i niemodnie, a tramwaj, którym jadą, kanciasty i skrzypiący, z trudem wlecze się po szynach. Na drewnianych ławkach ludzie tłoczą się jak szprotki w puszce, niektórzy wiszą nawet na zewnątrz wagonu! Najdziwniejsze jest jednak to, że tramwaj nie ma wcale drzwi. Po prostu na czas przejazdu wejście zabezpiecza się zwykłym sznurem (Rutka, s. 84).

Podobną funkcję - szokującej konfrontacji dwóch rzeczywistości - pełni obraz dworca, miejsca spotkań ludzi, symbol przestrzeni wędrowców, metafora czasu i podróży, odjazdów, rozstań i powrotów, powitań i pożegnań. Bohaterki obserwują zaryglowany hermetycznie ciemny pociąg bez okien wjeżdżający na stację i reakcję ludzi po wyjściu z wagonu na widok dworca - celu podróży. Oswajaniu obrazu nie pomaga dziecięce widzenie świata - jest w tym fragmencie narracji widoczna wyraźnie „dorosła” już desperacja: zawód i lęk, ból i rozpacz i prośba o pomoc, co odnajdują w analizowanym passusie także uczniowie.

Wokół maleńkiego, drewnianego budynku stacyjki [jest] diabelska plątanina torów, po których zewsząd przybywają pociągi. Są (...) brzydkie i złowrogie. (...) Te wagony nie mają okien, co najwyżej jeden zakratowany otwór, przez który do ciemnego wnętrza wpada zaledwie trochę światła i świeżego powietrza. Ciężkie, żelazne drzwi zaryglowano metalowymi sztabami. A mimo to podróżują nimi ludzie. Wielobarwny tłum wylewa się na zewnątrz od razu, gdy pociąg zatrzymuje się przy rampie. I zaraz potem w górę wzbija się lament we wszystkich językach świata. Jest w nich zawód i lęk, prośba o pomoc i niezgoda na to, że cel podróży okazał się tak inny od oczekiwań. Rutka zdradza Zosi, że ci ludzie ściągnęli tu z najpiękniejszych miast Europy: Paryża, Wiednia, Pragi, Rzymu i Budapesztu. - Ale po co? - nie może nadziwić się Zosia. - Gdybym mieszkała w tak cudownym miejscach, nigdy nie przeprowadziłabym się do Łodzi. - Ale z ciebie głuptas. Ich nikt nie pytał, czy chcą tu przyjechać, rozumiesz? - mówi Rutka z naciskiem (Rutka, s. 103-104-105).

\section{Metafora w wymiarze indeksowym - zatrzymanie narracji jako „chwyt udziwnienia" (scena jedzenia pączków, obraz motyli)}

Do narzędzi poetyki kognitywnej należy także zabieg „defamiliaryzacji tematu”, czyli „chwyt udziwnienia” narracji, polegający na wyobcowaniu czytelnika „względem pewnych aspektów świata”, w celu ukazania mu go na nowo, w oryginalny sposób. Do takich należą polisensoryczne w swej strukturze narracyjnej sceny np. jedzenia pączków oraz obraz motyli wylatujących z otwartych nagle niemieckich wagonów przewożących ludzi. Oba obrazy ewokują pozytywne emocje związane z radością i szczęściem - oddziaływanie kolorów, smaków i zapachów jest intensywne i wyraziste, co bohaterki wyrażają expressis verbis.

Sensulano-mentalne obrazy wywołują narracyjne napięcia o charakerze afektywnym. Wnętrza starych kamienic są brudne i pachną „zawilgoconym 
drewnem“, ale w jednym z pomieszczeń znajduje się „coś absolutnie cudownego“. Dziewczynki

zamierają z zachwytu, wpatrzone w kuchenne blaty, na których piętrzą się całe stosy rumianych, dopiero co upieczonych pączków. W misach skrywają się kolejno smakołyki: różana marmolada, krem maślany, kakaowa legumina, wreszcie cynamonowy cukier puder. [Rutka i Zosia] stoją jak wryte, słychać tylko przełykanie śliny. Macie pół godziny. Możecie jeść do syta. (...) Uszczypnij mnie, ja śnię... - mówi pierwsza rozmarzonym głosem i wkłada palec do najbliższej miski. - Szkoda czasu na szczypanie, gdy jest tyle roboty - odpowiada druga i wkłada do tej samej miski całą dłoń. Nabiera gęstą masę i wpycha ją sobie do ust, brudząc przy okazji nos, czoło i lewe ucho. Żółtawy krem jest lekki i puszysty jak bita śmietana, ale sto razy od niej smaczniejszy. Pachnie mlekiem, wanilią i czymś, co trudno nazwać, ale kojarzy się Zosi z domem i mamą (Rutka, s. 160).

Według Rembowskiej-Płuciennik taką strategię narracyjną opisu świata można by nazwać fokalizacją zmysłową. Powyższy fragment to nie tylko reprezentacja cudzych myśli czy stanów wewnętrznych, ale rodzaj fokalizacji, która „ewokuje rzeczywistość dla czytelnika sprawdzalną, weryfikowalną jego własnym doświadczeniem zmysłowym (...), jest środkiem apelowania do uniwersalnych reakcji, (...) pozwala na ingerencję wielozmysłowego odbioru świata na podstawie pamięci i empirycznego doświadczenia czytelnika oraz jego projektowanych scenariuszy przyszłości“" (Rembowska-Płuciennik 2015, 310; Bortolussi, Dixon 2003). Głód bohaterki i radość ze spożywania pączków ma tu charakter znaczeniotwórczy, determinuje całą serię leksykalnych skojarzeń związanych z rozkoszą i zachwytem i implikuje w umyśle czytelnika/ucznia obrazy mentalne związne $\mathrm{z}$ węwnetrznym światem uczuć bohaterki - emocjami kojarzonymi z ciepłem i bezpieczeństwem rodzinnego domu oraz miłością matki.

Naturalna zmysłowość reakcji dziecka na rzeczywistość, jego „zanurzenie" w percepcję dźwięku, smaku i zapachu może mieć wpływ na rozumienie tekstu, komunikowanie znaczeń i kształtowanie postaw etycznych, co wyrażają uczniowe w swoich pracach, uwzględniając cały szereg epitetów kojarzących się ze smakiem pączków, „słodkim szczęściem“ i sytością („głodna Rutka wreszcie mogła się najeść“; „świat dla Rutki stał się znowu słodki“; „najbardziej lubię pączki z marmoladą i lukrem - ciekawe, jakie lubi Rutka?").

Kolejna analizowana $\mathrm{z}$ uczniami scena to obraz przedstawiający moment otwarcia wagonu pociągu. Wychodzących z pociągu ludzi symbolizują wylatujące z otwartego wagonu motyle - stają się one w odczuciu dzieci wyrazistą metaforą wolności. Scena - jak zauważają dojrzale uczniowie - ma charakter poetycki i symbolizuje ucieczkę od zniewolenia oraz radość z odzyskania swobody. Wielobarwne motyle - jak piszą uczniowie - to także odzwierciedlenie wielo-kolorowości świata, różnorodności ludzi, rozmaitości i wielości ludzkich spojrzeń. Niebieskoskrzydłe motyle Morpho didius znaczą natomiast niebo i szczęście, za którym tęsknią i o którym 
marzą cierpiący ludzie; motyle lśnią i mienią się w słońcu jak diamenty, a posrebrzany blask trawy przywołuje w umysłach bohaterek - znajdującą się gdzieś daleko w galaktyce - Diamentową Planetę.

Odbiór tego fragmentu tekstu wzmacniają także rysunki dzieci.

Diamentowa Planeta przypomina fantastyczną krainę Nangijalę z baśni - Bracia Lwie Serce Astrid Lindgren - dla niektórych uczniów jest to miejsce śmierci i tortur, dla innych - niebo i raj.

Czy one lecą na Diamentową Planetę? Tam, gdzie są już twoi rodzice? Zosia patrzy na Rutkę i czuje, że jej samej robi się w środku jakoś gorzko i kwaśno, jakby zjadła właśnie cytrynę ze skórką. (...) Tak. Rodzice są już na pewno bardzo daleko. Nie wiem, czy można ich jeszcze dogonić - A najszybszym pociągiem? A warszawskim metrem. Rutka milczy, jakby nie słuchała Zosi. - Samolotem? Motorówką? Rakietą? - ta nie daje za wygraną, tak bardzo chce pomóc przyjaciółce (Rutka, s. 108, 111).

Oprócz perspektywy poetyckiej - ze względu na wyeksponowaną w tekście sytuację dialogową, w której uobecnia się reakcja Zosi na cierpienie przyjaciółki i deklarowana tym samym pomoc - widać dynamiczny charakter działań i „wpisane w tekst” wypowiedzi emocjonalne, które nie działają tu jako formuły „konstatujące” ani „performatywne” (implikujące działanie), ale pełnią funkcje „emotywne” i są swoistym aktem komunikacyjnym (Paivio 1971; 1991; Knuuttila 2015).

\section{Od czytania empatycznego po imersje (emocjonalna identyfikacja z bohaterką)}

W reakcjach dzieci na tekst widać spontaniczność, świeżość, przeżywanie, współodczuwanie świata, a nie opisywanie go. Wraz z opisywanym światem następuje „prezentacja własnych przeżyć i nastrojów” i odpowiedzi na pytania: JAK JA CZUJĘ TEN ŚWIAT? - JAK JA SIĘ CZUJĘ W TYM ŚWIECIE? Czytanie empatyczne wiązałoby się tu z dwoma rodzajami identyfikacji ze światem tekstowym: 1. identyfikacją izomorficzną - paralelną (stosunek między relacjami, z których jedna stanowi odwzorowanie drugiej; literacki świat i relacje są odwzorowaniem rzeczywistego świata, w którym żyje dziecko). W tym przypadku będą to dwa równoległe przestrzennie, ale odmienne/różne czasowo światy bohaterek: Zosi i Rutki: rzeczywisty - współczesny i wyobrażony - przeszły; 2 . identyfikacją immersyjną („krzyżowanie się” światów, zanurzanie się w nie). W tym przypadku będzie to $\mathrm{np}$. identyfikacja z wyobrażoną przyjaciółką - rówieśnicą i współodczuwanie świata wraz z nią. Samotność Zosi „przenika się“/nakłada/krzyżuje z samotnością Rutki. W obu przypadkach fantazja staje się remedium ucieczką od samotności okrutnej/przygnębiającej/ponurej rzeczywistości/ codzienności, co świetnie odnajdują także mali czytelnicy, odkrywając właściwy fragment utworu.

To takie straszne uczucie - być samemu. Nawet jeszcze gorsze od czkawki, bo tę można zalać wodą i zniknie. A samotności, choćbyś ją zalewała całymi wiadrami 
łez, nie sposób ugasić. Robi się bardzo smutno i naprawdę mało brakuje, a Zosia by się rozpłakała. Jednak decyduje się zatrzymać łzy na bardziej dramatyczne okazje, bo nigdy nie wiadomo, kiedy mogą się przydać (Rutka, s. 45).

Podobną funkcję pełni opis narysowanej na podłodze i ścianach rodziny Rutki. Siła wyobraźni Rutki jest ogromna - dziewczynka nie tylko tworzy wymyślony dom z postaciami, meblami, przedmiotami, ale także uczuciowo się z nim identyfikuje. Wyobrażony świat rodzinnych relacji i rodzicielskiej miłości w umyśle bohaterki na chwilę ożywa, oferując dziewczynce namiastkę ciepła i bezpieczeństwa.

Historia Rutki i jej spotkanie z rodzicami, którzy wychodzą po nią z ram zdjęcia, zamyka się w poetycki sposób sceną oniryczną. Małe bohaterki wraz z ciotką Różą stają znowu na łódzkim dworcu, skąd kiedyś odjechali na Diamentową Planetę rodzice Rutki. Pamięć przeszłości uobecnia się na kolejowej stacji we fragmentach „podartej” jak papier rzeczywistości: przedmiotach, listach, rozsypanych zdjęciach, kawałkach potłuczonej porcelany, zdekompletowanych zbiorach sztućców. Ale także na listach z nazwiskami prawdziwych - realnych przyjaciół, znajomych, sąsiadów i rodziny:

Fajgel, Blum, Dancinger, Fogelman, Rychter... Wszyscy oni wyruszyli stąd kiedyś na Diamentową Planetę. Nie bój się - mówi ciotka Róża. To miejsce pełne jest śladów i wspomnień, dlatego niektórym przedmiotom wydaje się, że ich właściciele zaraz po nie wrócą. Spójrzcie, one wszystkie czekają (Rutka, s. 212).

Zosia rozpoznaje wreszcie dwie ukochane osoby. Ciotka Róża i Rutka „zlewająjej się w jedną postać - stara kobieta i mała dziewczynka zamknięte w tej samej duszy" (Rutka, s. 213).

Emocjonalne zaangażowanie czytelnika, czytanie empatyczne i immersyjna identyfikacja czytelnika z bohaterką uwidaczaniają się także w bardzo osobistych listach, które piszą do Rutki dzieci.

„Miałaś dużo nadludzkiej mocy, aby przetrwać bez rodziców”; „jak Ci się udało nie popaść w depresje i kompletną samotność?”; „wszystko, co się z Tobą działo, było smutne i przykre, ale dzięki swojej [zwariowanej] wyobraźni potrafisz czasami przestać myśleć, że Twoja rodzina nie wróci”; „czytając Twoją historię, czułam smutek, bo czasy, w których żyłaś, były bardzo trudne, ale ty byłaś silniejsza i dzielniejsza niż niejeden dorosły”; "dzięki tobie muszę spróbować morwy, jeśli tak bardzo ci smakowała”; „Współczuję Ci, że straciłaś rodziców i brata, ale Twoja historia pokazuje, jak pobudza do życia wyobraźnia, dodaje wiary i odwagi w siebie”; „Mimo tego, że jesteś biedna i nie masz pięknych i barwnych ubrań - bardzo Cie polubiłam”; „Twoja historia mnie poruszyła”, „Współczuje ci!”; „Uważam, że jesteś magiczna, potrafisz chować się do szuflady i szybko się zaprzyjaźniasz”; „Masz swój świat i bogatą wyobraźnię, w Twoim świecie wszystko jest inne: trawa i rzeka są czerwone, a w opuszczonym domu mieszkają [„wymyśleni”] ludzie”; „Podczas 
czytania książki o Tobie wzruszyłam się i prawie się popłakałam, bo odnajdujesz [jednak] rodziców; uważam, że to jest słodkie i wzruszające”; „Dla mnie Rutka jest bardzo silna w sensie emocjonalnym”.

\section{Konkluzja - od poziomu polisensorycznych obrazów przez emocje po etyke}

Jak zauważono powyżej, „czytanie zaangażowane” czy - posługując się tu terminem Ingardena - czytelnicza konkretyzacja ( $\mathrm{z}$ „dookreślaniem znaczeń") związane jest nie tylko z postrzeganiem, rozumieniem, wyobraźnią, wiedzą, podobieństwami i kategoryzacją, ale także doświadczeniem. Aspekt „doświadczenia” uwzględniają także komentujące lekturę prace dzieci.

Doświadczeniowa wyrazistość przez swą funkcję ekspresywną przywołuje uczucia i emocje związane z codziennością - angażuje nie tylko językową, ale i pozajęzykową aktywność umysłu oraz odsyła do obszarów pozatekstowych (czytanie eferentne wg Rosenblatt). Świat narracji Fabickiej jest bowiem poetycki (np. w scenie przywołania kołysanki z dzieciństwa Rutki), metaforyczny (np. w scenie przedstawiającej obraz dworca z czasów wojny) i surrealistyczny (np. w scenie opisującej motyle - obrazujące wolność pasażerów opuszczających wagon pociągu). Dziecięca zdolność do obrazowania świata, ich wyobraźnia mentalna oraz konsekwentna konfrontacja literackiej fikcji ze światem rzeczywistym uświadamia, iż kognitywne spojrzenie na literaturę dla dzieci $\mathrm{w}$ połączeniu $\mathrm{z}$ uczuciowym aspektem lektury może być jednym z metodologicznych tropów. Na przykład dzieci zauważają: „Zosia radzi sobie z samotnością, przenosząc się do świata wyobraźni".

Można by się zastanawiać, jaka jest dominująca, dostrzegalna emocja w tekście: SMUTEK? ŻAL? PRZYGNĘBIENIE? BÓL? TĘSKONTA? OCZEKIWANIE? NADZIEJA? WEWNĘTRZNA MOBILIZACJA? PRÓBA PRZEZWYCIĘŻENIA ROZPACZY? Wydaje się, że te wszystkie emocje tworzą w utworze swoisty klaster, który mieści w sobie szeroko pojęte postawy etyczne. W wypowiedziach dzieci mamy bowiem nawiązania do niektórych, kluczowych dla krytyki kognitywnej, pojęć, np. teorii umysłu, empatii, identyfikacji, zaangażowania emocjonalnego, imersyjnej i empatycznej identyfikacji. Z prac uczniów wynika, że te kategorie są dla nich istotne. Warto także wyróżnić mimowolnie/intuicyjnie zastosowane przez uczniów w wypo-

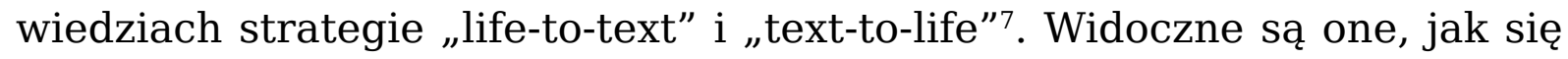
zdaje, głównie podczas oceny opisu wewnętrznych światów obu bohaterek (tu: samotności i działającej w obu przypadkach wyobraźni), ale także podczas ustosunkowania się („pozycjonowania się”) do poszczególnych

\footnotetext{
${ }^{7} \mathrm{~W}$ budowaniu znaczenia utworu oraz jego interpretacji pomagają różne strategie czytania tekstu; sugerują one odwołania do rzeczywistości, do innego tekstu, „do siebie” (np. text-to-world, textto-self, text-to-text e.t.c.); zob. https://www.facinghistory.org/resource-library/teaching-strategies/ text-text-text-self-text-world [data dostępu: 11 XI 2016]
} 
dorosłych bohaterów - ciotki Róży (Stockwell tu np. wprowadziłby termin positioned reader).

Opowieść Fabickiej zdecydowanie ma potencjał, aby wzmacniać czytanie empatyczne oraz proces identyfikacji czytelników z głównym bohaterem.

Na lekcjach pojawiają się także pytania najważniejsze: Dlaczego Zosia zaprzyjaźnia się z Rutką? Czym jest przyjaźń dla obu dziewczynek? Dlaczego Rutka i Zosia budzą nasze współczucie?

Przez uruchamianie emocji uczniowie angażują się emocjonalnie w postać bohaterki i piszą: lubimy Rutkę za to, że jest postacią tajemniczą, cenimy za jej siłę charakteru, za to, że „nie udało jej się popaść w depresję, i kompletną samotność“, za odwagę, wytrwałość, szczerość, uczuciowość, serdeczność, Dzięki takim wnioskom uczniowie pogłębiają rozumienie przeżyć i zachowań postaci literackich, budzą się także refleksje nad ich własnym zachowaniem.

Wizualizacja efektów i afektów oraz metaforyzacja obrazów wzmacnianych doświadczeniem rzeczywistym mogą wpływać na emocjonalne zaangażowanie czytelników oraz wywierać wpływ na konstruowanie przez nich nowych znaczeń i sensów utworu. Łączenie aspektów czytania estetycznego (np. opisu motyli) z odbiorem eferentnym (np. przez uwzględnienie kontekstu egzystencjalnego i etycznego w tym sytuacji rodziny $\mathrm{w}$ obliczu wojny) przez np. czytanie fragmentów eksponujących narrację polisensoryczną wzmacnia siłę interakcji, jaka zachodzi między słowem, obrazem i emocjami, co przekłada się w tym przypadku na wspomaganie rozumienia, kształtowanie wyobraźni i formułowanie etycznej refleksji nad światem.

\section{Bibliografia}

Assmann Jan, 2009, Kultura pamięci, w: Pamięć zbiorowa i kulturowa. Wspótczesna perspektywa niemiecka, Saryusz-Wolska M. (red.), Kraków.

Bachelard Gaston, 1975, Wyobraźnia poetycka, Tatarkiewicz A. (przeł.), Warszawa.

Biedrzycki Krzysztof, Janus-Sitarz Anna (red.), 2002, Doświadczanie lektury. Między krytyka literacka a dydaktyka literatury, Kraków.

Bortolussi Marissa, Dixon Peter, 2003, Psychonarratology, Foundations of Empirical Study of Literary Response, Cambridge.

Bosmajan Hamijda, 2002, Sparing the Child: Grief and the Unspeakable in Youth Literature about Nazism and the Holocaust, Psychology Press.

Budrewicz Zofia, 2012, Odbiorca szkolnej lektury jako podmiot doświadczajacy w: Doświadczenie lektury. Między krytyka literacka a dydaktyka literatury, Biedrzycki K., Janus-Sitarz A. (red.), Kraków.

Chrząstowska Bożena, 1987, Lektura i poetyka, Warszawa.

Etkind Aleksander, 2013, Warped Mourning: Stories of the Undead in the Land of the Unburied, Stanford, CA: Stanford University Press.

Foucault Michel, 2005, Inne przestrzenie, „Teksty Drugie”, nr 6. 
Galda Lee, Liang Lauren, Sipe Lawrence, Cullinan Bernice, 2013, Literature and Child, wyd. 8, Cengage Learnig.

Hirsch Marianne, 1997, Family Frames: Photography, Narrative, and Postmemory, Cambridge, Harvard.

Hirsch Marianne, 2011, Żałoba i postpamięć, w: Teoria wiedzy o przeszłości na tle współczesnej humanistyki, Domańska E. (red.), Poznań.

Hobbs Jerry, 1990, Literature and Cognition, Stanford: Johns Hopkins University Press.

Hunt Peter, Narrative Theory and Children's Literature, Children's Literature Association Quarterly, Volume 9, Number 4, Winter 1984-1985 , pp. 191-194 (data dostępu: 20 X 2016).

Janus-Sitarz Anna, 2016, W poszukiwaniu czytelnika. Diagnozy, inspiracje, rekomendacje, Kraków.

Kertzer Adrienne, 2002, My Mother's Voice. Children, Literature, Holocaust, Broadview Press.

Knuuttila Simo, Bodily Dialogues. Indexicality of Emotion in Literary

Experience, zob. http://emocje-a-kultura.wikispaces.com/

Emocje $+w+$ naukach $+o+$ literaturze+-+Sirkka+Knuuttila+i+inni (data dostępu: 15 IV 2016) oraz http://www.academia.edu/217942/Bodily_Dialogues. Indexicality of Emotion in_Literary_Research (data dostępu: 20 X 2016).

Kokkola Lydia, 2003, Representing Holocaust in Children's Literature, Routledge.

Koziołek Krystyna, 2016, Czas lektury, Katowice.

Lansberg Alison, 2004, Prosthetic Memory: The Transformation of American Remembrance in the Age of Mass Culture, New York.

Levine Michael G., 2006, The Belated Witness: Literature, Testimony, and the Question of Holocaust Survival, Cultural Memory in the Present, Stanford University Press.

Lindauer Martin, 1974, The Psychological Study of Literature, Chicago: Nelson-Hall.

Małecki Wojciech, Pawłowski Bogusław, Sorokowski Piotr, 2016, Literary Fiction Influences Attitudes Toward Animal Welfare, zob. PLoS ONE 12(2): e0172328. https://doi.org/10.1371/journal.pone.0172328

Maryl Maciej, Interpretator czy czytelnik? Projekt badań empirycznych nad stylami odbioru, http://www.academia.edu/5544682/Interpretator_czy czytelnik_Projekt bada\%C5\%84 empirycznych nad stylami odbioru.

Maryl Maciej, 2015, Sztuka czytania? Mieke Bal w teorii i praktyce [The art of reading? Theory and practice of Mieke Bal] „Teksty Drugie”, nr 4 (142), s. 312-326.

Miall David, Kuiken Don, 1998, The Form of Reading. Empirical Studies of Literariness „Poetics”, nr 25.

Miall David, 2006, Literary Reading: Empirical and Theoretical Studies. New York: Peter Lang, August.

Nikolajeva Maria, 2014, Reading for Learning. Cognitive Approaches to Childrens Literature, Cambridge. 
Nycz Ryszard, 2007, Antropologia literatury - kulturowa teoria literatury poetyka doświadczenia, „Teksty Drugie”, nr 6.

Opdahl Keith, 2002, Emotion as Meaning. The Literary Case for How We Imagine, Bucknell University Press Associated University Presses, London Cranbury, NJ.

Paivio Allan, 1991, Images In Mind. The Evolution of a Theory, Harvester Wheatsheaf, New York London.

Paivio Allan, 1971, Imagery and Verbal Processes, Holt, Rinehart and Winston, New York Chicago.

Papuzińska Joanna, 1995, Dziecko w świecie emocji literackich, Warszawa.

Patrzałek Tadeusz, 1980, Postawy uczniów dziesięcioletnich wobec lektury, „Polonistyka”, nr 6.

Patrzałek Tadeusz, 1982, Postawy uczniów jedenastoletnich wobec lektury, „Polonistyka”, nr 3.

Płuciennik Jarosław, 2002, Literackie identyfikacje i oddźwięki. Poetyka i empatia, Łódź.

Płuciennik Jarosław, 2014, Procesy kognitywne a czytanie i zmysły, w: http://dspace.uni.lodz.pl:8080/xmlui/bitstream/handle/11089/7235/ Procesy\%20kognitywne\%20Czytanie sensualno\%C5\%9B\%C4\%87. pdf? sequence $=1$ \&isAllowed =y [data dostępu: 10 I 2018]

Polakowski Jan, 1980, Badania odbioru prozy artystycznej $w$ aspekcie dydaktycznym. Zarys teorii badań - próby diagnozy, Kraków.

Rajtar Małgorzata, Straczuk Justyna (red.), 2012, Emocje w kulturze, Warszawa.

Rembowska-Płuciennik Magdalena, http://ibl.waw.pl/ rembowskapluciennikautoreferat.pdf (data dostępu: 20 X 2016).

Rembowska-Płuciennik Magdalena, 2009, Wizualne efekty i afekty. Obrazowanie mentalne a emocjonalne zaangażowanie czytelnika, „Teksty Drugie”, nr 6.

Rembowska-Płuciennik Magdalena, 2015, Poetyka intersubiektywności. Kognitywistyczna teoria narracji a proza XX wieku, Warszawa.

Rosenblatt Louise, 1995, Literature as exploration, Modern Language Association of America (pierwsze wyd. 1938).

Rosenblatt Louise, 1994, The reader, the Text, the Poem. The Transactional Theory of he Literary Work, Southern Illinois University Press.

Ryan Marie-Laure, 2003, Narrative as Virtual Reality: Immersion and Interactivity in Literature and Electronic Media, Parallax: Re-visions of Culture and Society.

Stockwell Peter, 2006, Poetyka kognitywna, Skucińska A. (przeł.), Kraków.

Strzemiński Władysław, 1974, Teoria widzenia, Kraków.

Ulanowicz Anastazja, 2013, Second - Generation Memory and Contemporary Children's Literature. Ghost Image, Routledge.

Vice Sue, 1997, Introducing Bakhtin, Manchester University Press.

Wójcik-Dudek Małgorzata, 2016, (Wy) Czytać zagładę. Praktyki postpamięci 
w polskiej literaturze XXI wieku dla dzieci i młodzieży, Katowice.

Zasacka Zofia, 2014, Czytelnictwo dzieci i młodzieży, Warszawa.

Żuchowska Wiesława, 1992, Oswajanie ze sztuka słowa. Poczatki edukacji

literackiej, Warszawa.

\section{O Autorce:}

Dorota Michułka - dr hab., kierownik Zakładu Metodyki Nauczania Języka Polskiego i Literatury Polskiej w Instytucie Filologii Polskiej (Uniwersytet Wrocławski); zajmuje się dydaktyką języka polskiego i historii, literaturą dla dzieci i młodzieży, kształceniem literacko- kulturowym (także w ujęciu historycznym), szkolną recepcją literatury i kultury; w latach 20002005 pracowała jako lektor języka polskiego w Finlandii (Slaavilainen filologian laitos, Tampereen yliopisto, Suomi); stypendystka Department of Social Science, University of Leiden w Holandii, University of Minnesota, Minneapolis, College of Education and Human Development w USA i Internationale Jugendbibliothek w Monachium (Niemcy); uczestniczka projektu pilotowanego przez Institut National de Recherche Pédagogique (INRP, Lyon, Francja); jest autorką dwóch monografii, ok. 140 artykułów wydanych w Polsce i za granicą oraz redaktorką i współredaktorką kilku książek wydanych w Polsce i Finlandii; także zastępcą redaktora naczelnego międzynarodowego czasopisma „Filoteknos”, poświęconego badaniom literatury dziecięcej; jest członkiem IRSCL

\section{O Autorze:}

Łukasz Gregorowicz - magister, nauczyciel języka polskiego, terapeuta pedagogiczny, wychowawca; pracuje z uczniami szkoły podstawowej i gimnazjum. W ramach współpracy z Zakładem Metodyki Nauczania Literatury i Języka Polskego Uniwersytetu Wrocławskiego od kilku lat pełni funkcję szkolnego opiekuna metodycznego studentów filologii polskiej na specjalności nauczycielskiej. W pracy z uczniami zwraca szczególną uwagę na terapeutyczne aspekty kształcenia literackiego i językowego. Interesuje się dydaktyką języka polskiego oraz historią literatury. 